Fairness in Sovereign Debt - Barry - 2007 - Ethics \& International Affairs - Wiley Onl... Page 1 of 4

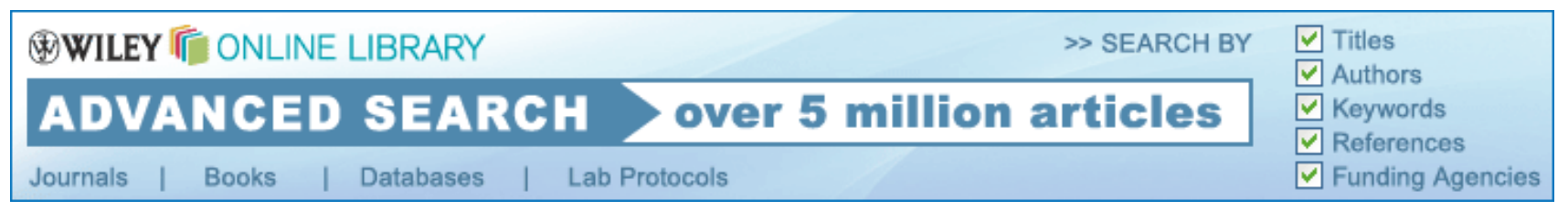

You have full text access to this content

\title{
Fairness in Sovereign Debt
}

1. Christian Barry,

2. Lydia Tomitova ${ }^{\dagger}$

Article first published online: 27 NOV 2007

DOI: 10.1111/j.1747-7093.2007.00084.X

Issue

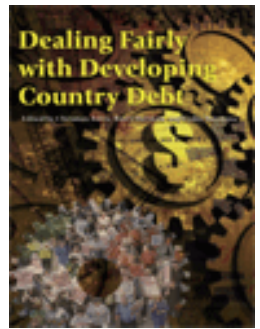

\section{Ethics \& International Affairs}

Volume 21, Issue Supplement s1, pages 41-79, November 2007

Additional Information

How to Cite

Barry, C. and Tomitova, L. (2007), Fairness in Sovereign Debt. Ethics \& International Affairs, 21: 41-79. doi: 10.1111/j.1747-7093.2007.00084.x

\section{Author Information}

$\dagger$

A version of this essay was published in Social Research 74, no. 2 (2006), pp. 649-69. It draws on two working papers by Christian Barry: "Ethical Issues Relevant to Debt," and "A dívida soberana como problema ético: algumas considerações preliminares.” We are grateful for comments by Michael Cohen, Álvaro de Vita, Sakiko Fukuda-Parr, Ludmila Palazzo, Thomas Pogge, Kunibert Raffer, Sanjay Reddy, and Alys Willman-Navarro, and especially to Barry Herman and Robert Hockett for their detailed written comments. We are also grateful to the Ford Foundation for providing funding for the project "Ethics and Debt," and to the Carnegie Council for supporting our work.

\section{Publication History}

1. Issue published online: 27 NOV 2007 
Fairness in Sovereign Debt - Barry - 2007 - Ethics \& International Affairs - Wiley Onl... Page 2 of 4

2. Article first published online: 27 NOV 2007

- Abstract

- Article

- Cited By

View Full Article (HTML) Get PDF (177K)

First page of article 


\section{Fairness in Sovereign Debt Christian Barry and Lydia Tomitova*}

W -hen can we say that a debt crisis has been resolved fairly? That is, what makes processes of debt restructuring, debt cancellation, or the enforcement of debt contracts more or less fair, or the outcomes of such processes better or worse? These are not idle questions. The recent economic collapse in Argentina and financial crisis in Turkey, and the persistent unsustainable debt burdens of many developing countries highlight the practically urgent problem of excessive indebtedness. High debt levels can limit a sovereign government's capacity to provide social services necessary for the well-being of its citizens, and divert resources and energy from the pursuit of long-term development strategies. In addition, after a government defaults, the mechanisms for managing the restructuring of sovereign debt usually act slowly, do not return the country to debt sustainability, and often leave the different classes of creditors as well as the people of the indebted country feeling as if they have been treated unfairly. This in turn can create disincentives for lending and investment that can be crucial to the prospects of developed and developing countries alike. An often overlooked but very important effect of financial crises and the debts that often engender them is that they can lead the crisis countries to increased dependence on international institutions and the policy conditionality they require in return for their continued support, limiting their capabilities and those of their citizens to exercise meaningful control over their policies and institutions.

These outcomes have been viewed by many not merely as extremely unfortunate and regrettable, but also as deeply unfair. And indeed, increasingly

\footnotetext{
* A version of this essay was published in Social Research 74, no. 2 (2006), pp. 649-69. It draws on two working papers by Christian Barry: "Ethical Issues Relevant to Debt," and "A dívida soberana como problema ético: algumas consideraçōes preliminares." We are grateful for comments by Michael Cohen, Álvaro de Vita, Sakiko Fukuda-Parr, Ludmila Palazzo, Thomas Pogge, Kunibert Raffer, Sanjay Reddy, and Alys Willman-Navarro, and especially to Barry Herman and Robert Hockett for their detailed written comments. We are also grateful to the Ford Foundation for providing funding for the project "Ethics and Debt," and to the Carnegie Council for supporting our work.
} 
Fairness in Sovereign Debt - Barry - 2007 - Ethics \& International Affairs - Wiley Onl... Page 4 of 4

View Full Article (HTML) Get PDF (177K)

\section{More content like this}

Find more content:

- like this article

Find more content written by:

- Christian Barry

- Lydia Tomitova

- All Authors 